Rapp. Grønlands geol. Unders. 112, 53-69 (1983)

\title{
The Malene metasedimentary rocks on Rypeø, and their relationship to Amîtsoq gneisses
}

\author{
R. F. Dymek, R. Weed and L. P. Gromet
}

\begin{abstract}
Two groups of Malene metasedimentary rocks on Rypeø, a small island south of Godthåb, have been studied in detail in order to evaluate their origin and relationship to older, adjacent Amîtsoq gneiss.

Field observation shows that the metasediments range from massive to finely layered, and include an unusual pod-rock ('pseudoconglomerate'), which probably represents a series of deformed sedimentary layers (or lenses) of contrasting competence. Petrographic study indicates that the metasediments are quartz-rich, contain abundant plagioclase and biotite, and small but variable amounts of sillimanite, muscovite, microcline and garnet. Rare earth elements (REE) in samples of four metasedimentary lithologies are similar to some published analyses of 'tonalitic' Amitsoq gneiss.

These observations suggest that the protolith of the Malene metasediments on Rypeø was dominated by sandstone type lithologies which evolved in a near-shore tidal to fluviatile environment. These sediments were probably derived by weathering and erosion of Amitsoq gneiss and deposited unconformably on such a gneissic basement.

Petrological study indicates that the Rypeø metasediments were metamorphosed to the beginning of Musc + Qtz breakdown (Musc-Sill-Kfsp transition zone), and locally underwent minor amounts of melting. The proposed original unconformable contact relationships, coupled with high-grade polymetamorphism - not only of the supracrustal rocks but also of Amîtsoq gneiss - indicates substantial vertical crustal movement, perhaps as much as $75 \mathrm{~km}$ since the time of formation of Amîtsoq gneiss at $\sim 3750 \mathrm{Ma}$.
\end{abstract}

\section{Introduction}

One of the more intriguing and controversial problems remaining in the Archaean craton of West Greenland concerns the relationship between the $c .3750$ Ma Amitsoq orthogneisses and the $>3000 \mathrm{Ma}$ Malene supracrustals. McGregor (1973) first recognized the regional lithostratigraphic units in this area and posed two alternative models: (a) the Amitsoq gneisses constitute a basement on which younger supracrustal rocks were deposited, with the original relationships obscured by later deformation; (b) the gneisses and supracrustals formed in separate regions of the Earth and were juxtaposed by later thrusting. Because of the abundance of metavolcanic amphibolite in the Malene supracrustals, Bridgwater et al. (1974) suggested that they may represent a volcanic/sedimentary assemblage with oceanic-crustal affinity, although those authors did allow for a 'continental' source of some metasedimentary lithologies. Chadwick \& Nutman (1979) noted thin $(<1.5 \mathrm{~m})$ horizons of green mica quartzite and local discordance between gneisses and supracrustals in the northwest Buksefjorden region. They interpret these features in terms of a basement-cover un- 
conformity subsequently modified by thrusting, although they regard the majority of contacts as tectonic. We visited these localities in 1979 and 1980 and agree that the contact zones are strongly tectonized and locally discordant, but the field relations are ambiguous with respect to the original nature of the gneiss-supracrustal boundary. Beech \& Chadwick (1980) have also noted the intervening green mica rocks at the possible unconformity in the northwest Buksefjorden area, though they continue to regard the Malene amphibolites as the 'basal' lithology in the rest of the region.

There are other localities in the Godthåb district however, particularly the small islands south of Godthåb, where the relationships between Amîtsoq gneiss and Malene supracrustal rocks are also suggestive of an unconformable contact. On Simiutâ, a gently undulating contact separates metaquartzites and sillimanite-rich Malene green mica paragneisses from granodioritic Amitsoq orthogneiss (Nutman \& Bridgwater, 1983).

On Rypeø, a thick section of quartz-rich brown Malene paragneisses containing pseudo-conglomeratic horizons abuts directly onto Amîtsoq gneiss. On Mitsimavigssuaq, arkosic Malene paragneisses are interlayered with Amitsoq gneiss, but structural imbrication causes repetition of the section here, and complicates interpretation of the contact relationships. On the Lille Narssaq peninsula, we identified pale brown gneiss and quartzite at four localities; one of these exposures, occurring along the southernmost Amîtsoq-Malene contact, is continuous for at least $2 \mathrm{~km}$ and reaches a thickness of $7 \mathrm{~m}$. Finally, within the principal supracrustal unit on Store Malene, there are continuous, thin $(<10 \mathrm{~m})$ horizons of

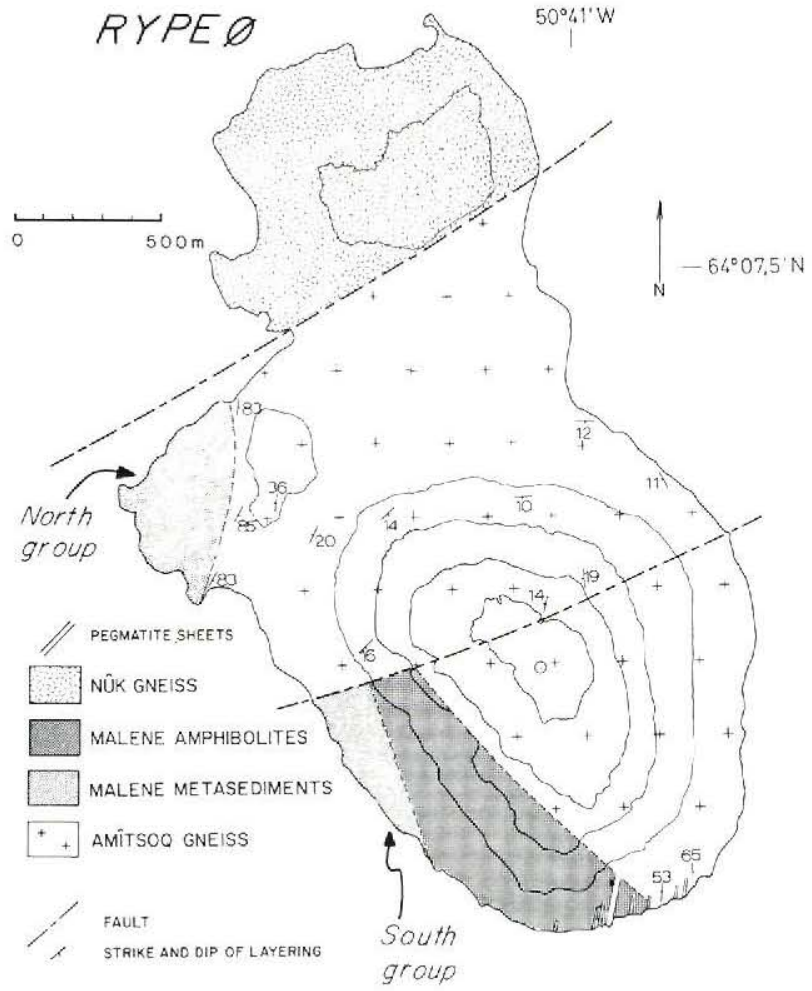

Fig. 1. Generalized geological map of Rypeø (modified from McGregor, 1973). 
Fig. 2. Geology of the northern group of Malene metasedimentary rocks on Rypeø. Details of the contact zone with Amîtsoq gneiss at localities 1 and 2 are described in the text. Akilia association refers to supracrustal (?) enclaves in Amîtsoq gneiss as defined by McGregor \& Mason (1977).

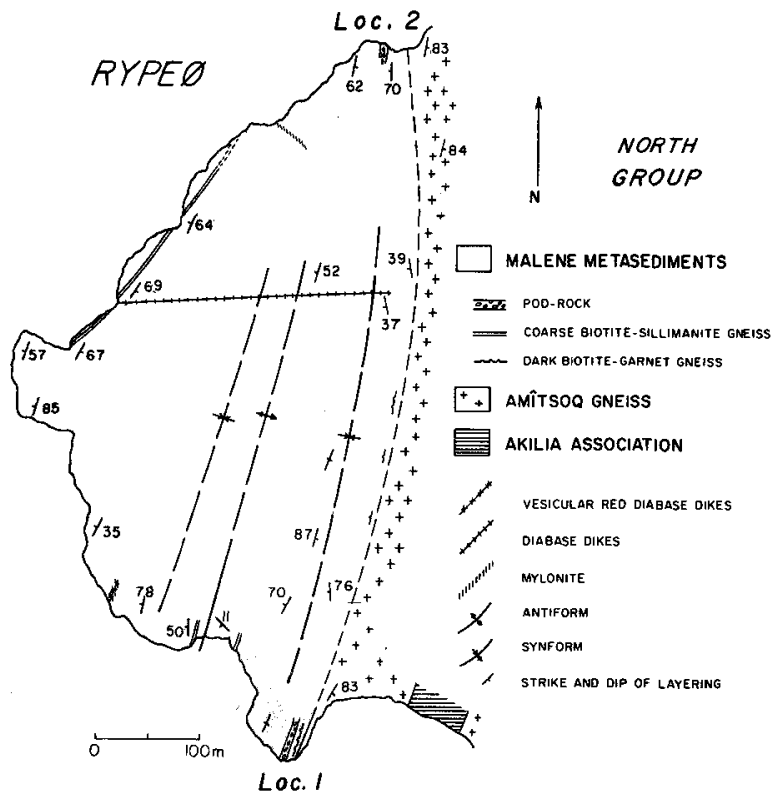

brown, 'gritty' paragneiss not unlike those observed at the other localities. The persistent regional association of these rock types suggests preservation of an original stratigraphic feature.

In an attempt to contribute useful information to the Amitsoq-Malene problem, we present here an extended description of the Malene metasedimentary rocks on Rypeø, the locality which we have studied in greatest detail. We also present the results of petrological and geochemical (rare earth element) studies of selected supracrustal lithologies there. Our data and observations are consistent with the concept that the metasediments were derived locally from Amîtsoq gneiss-type material.

\section{Geological overview}

The general geology of Rypeø is shown in simplified form in figure 1, modified from McGregor (1973). A heterogeneous suite of $c .3000$ Ma quartzofeldspathic Nûk gneiss forms the northern part of the island. These rocks are truncated by a major right-lateral transcurrent shear zone, the Kobbefjord Fault Zone. This zone, which is up to $100 \mathrm{~m}$ wide here, has been the site of extensive Proterozoic ductile to brittle deformation and hydrothermal alteration (Smith \& Dymek, 1983). A thick, sheared mafic dike occurs within the fault zone.

Amîtsoq gneiss and two groups of Malene supracrustal rocks crop out on the central and southern portions of the island. The northern group of Malene rocks (fig. 2) is comprised almost exclusively of folded pelitic to psammitic metasediments, whereas the southern group (fig. 3) includes similar metasedimentary rocks as well as metavolcanic (?) amphibolite. 


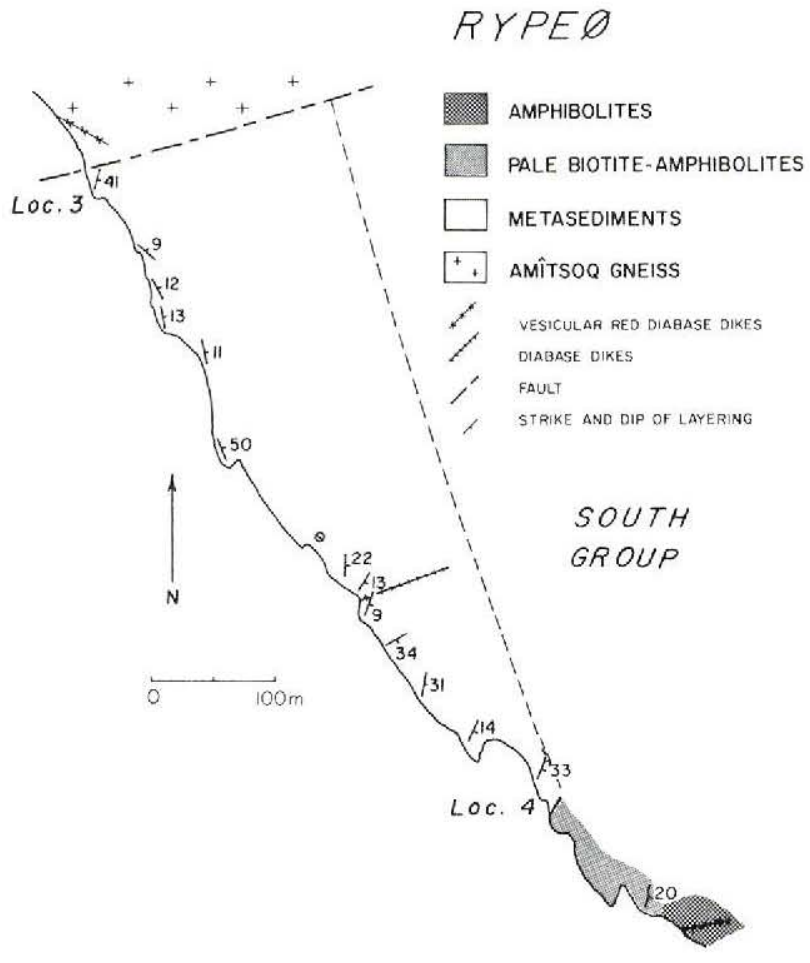

Fig. 3. Southern group of Malene supracrustal rocks on Rypeø. Descriptions of the contact zone at locality 3 , and the sequence of layered units at locality 4 are given in the text.

Thick pegmatite sheets of uncertain affinity occur at the contact between Malene amphibolite and Amitsoq gneiss in the southern part of the island.

There is a sheared mafic dike in a small fault zone that traverses the center of Rypeø, but the southernmost dike has not been affected by faulting (fig. 3). The parallelism between the three dikes and two faults suggests that transcurrent movement on Rypeø was localized along a pre-existing NE-SW oriented fracture system. The final rock unit recognized on Rypeø includes two occurrences of a later set of vesicular, red-weathering, diabase dikes.

\section{Description of supracrustal lithologies}

\section{General}

Pale brown, muscovite-bearing gneisses constitute the bulk of the metasedimentary rocks on Rypeø. Massive, quartz-rich types dominate, but they include less abundant layered sequences. These contain quartz + plagioclase + biotite \pm muscovite \pm sillimanite \pm garnet \pm microcline. In addition, a distinctive layer of 'pod-rock', possibly a conglomerate, forms a useful marker horizon. Other important supracrustal units on Rypeø include layered black amphibolite, locally garnet-bearing, and leucocratic biotite amphibolite. In the following sections, we present descriptions of these supracrustal sequences which focusses largely on the metasedimentary lithologies. 
Fig. 4. Diagrammatic stratigraphic column for the metasedimentary rocks at locality 1 (fig. 2). Unit 4 is the dark biotite-garnet gneiss whose location is indicated on figure 2 ; unit 6 is the 'pod-rock'. More complete descriptions of units $1-9$ are given in the text.

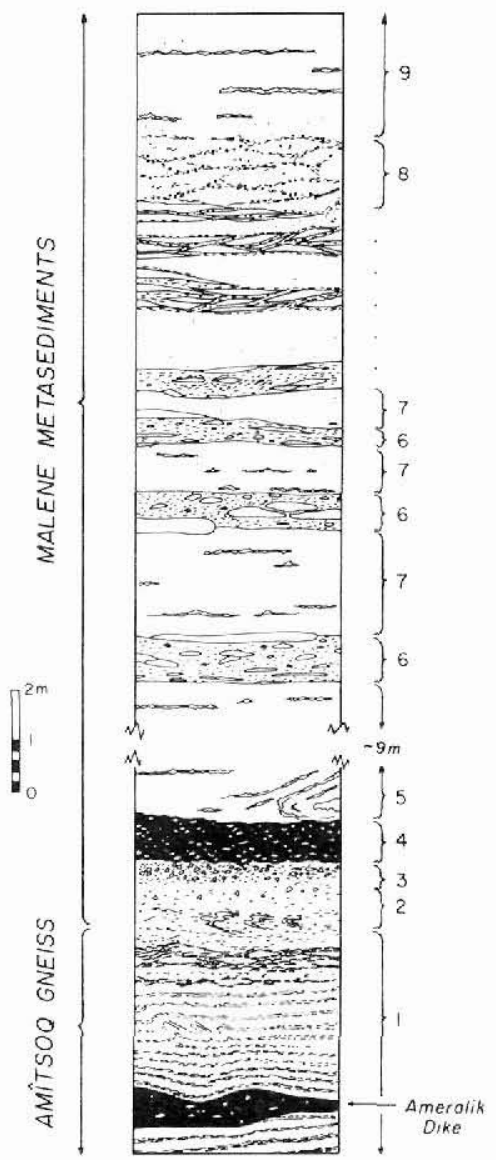

\section{Malene Metasedimentary Rocks}

Amîtsoq gneiss - Malene metasediment contact zone: northern supracrustal group

A persistent sequence of relatively thin but distinctive layers, all strongly tectonized, characterize the contact zone here (fig. 2). These units are summarized by means of a simplified stratigraphic column (fig. 4), which is based largely on observations made at locality 1 (fig. 2). We recognize that the dimensions shown on figure 4 can only approximate original thicknesses of these units, but the diagram may act as a framework for the following discussion.

The last several meters of Amîtsoq gneiss (Unit 1) range from an irregularly banded gneiss to a steeply dipping lithology with a well-straightened fabric. The final recognizable horizon of Amîtsoq gneiss grades from a microcline-rich, typically well-banded gneiss to a less cleanly layered variety. Several small, sheared-out pegmatitic folds in both the last Amîtsoq orthogneiss and first Malene pargneiss, indicate left-lateral movement in the contact zone. 
The first recognizable horizon of Malene metasediment (Unit 2) is a gray paragneiss. We note that it is difficult to point to a specific Amitsoq-Malene boundary in the field, but the presence of large, fresh plagioclase grains instead of microcline, very slight rusty weathering, and the absence of large zircons with polymetamorphic grain boundaries distinguish this first Malene unit.

Unit 3 is an extremely rusty gneiss with a coarse, irregular fabric. It contains $0.5-1 \mathrm{~cm}$ feldspar and quartz grains which may represent a clastic texture. Unit 4 is a dark horizon, rich in garnet and biotite, with sharp upper and lower contacts. As shown on figure 2, it can be traced inland for several hundred meters - despite poor exposure - where it maintains essentially the same stratigraphic position with respect to Amîtsoq gneiss.

Unit 5 includes several meters of a rusty-weathering parageneiss containing $\sim 75 \%$ quartz, $\sim 15-20 \%$ biotite and minor plagioclase, sillimanite and zircon. Centimeter-size pegmatitic segregations outline folding on a centimeter to meter scale in the lower part of this unit, and are consistent with the left-lateral movement direction noted above.

The next several meters are characterized by alternations of the 'pod-rock' (Unit 6; fig. 5a) and a pale massive quartz-rich gneiss (Unit 7). This pod-rock outcrops in two places on Rypeø (locality 1 and locality 2; fig. 2), occurring in a similar stratigraphic position in both cases.

The matrix of the pod-rock is poorly foliated, rich in quartz, and contains up to $25 \%$ garnet, $40 \%$ biotite and $15 \%$ plagioclase, but the proportions of these minerals vary widely. Accessory zircon, abundant pyrite and traces of secondary muscovite are also present. Hornblende aggregates (up to $7 \mathrm{~cm}$ across) occur locally in the matrix.

Most of the pods in this lithology are flattened quartz-rich ellipsoids ranging from $1 \times 5$ to $4 \times 30 \mathrm{~cm}$ in longitudinal cross-section. Closer examination of hand specimens shows that there are coarse quartz aggregates ranging down to $\mathrm{mm}$ size. In addition there are much larger pods - up to $15 \mathrm{~cm} \times 3 \mathrm{~m}$. These large pods invariably occur at the margins of the poddy horizons.

Although virtually all the pods are elongated, shapes do vary (fig. $5 \mathrm{~b}$ and $5 \mathrm{c}$ ) with no simple correlation to degree of deformation. Rounded ends on the larger pods even truncate the contact between the matrix of the pod-rock and the adjacent quartz-rich unit (7). At locality 2 (fig. 2), the long axes of pods diverge as much as 20 degrees from the general strike of this unit. In addition, matrix minerals are randomly oriented, and individual pods are much less flattened than at locality 1 . In the last few bands of the podrock, where the lithology is essentially all pods with garnet-biotite borders, the ends of individual pods are pinched-out, thus creating a horizon of interlayered lenses (fig. $5 \mathrm{~d}$ ). Here, pod boundaries become difficult to distinguish, and pods appear rather uniform in composition. However, there are no felsic pegmatitic stringers connecting neighboring pods, nor are there mafic selvages at pod margins.

The compositions of pods are also variable. Quartz is the dominant mineral, but grain size is highly variable, and shows no apparent correlation to pod size or degree of flattening or shear. Feldspar content ranges up to $30 \%$ : some pods contain abundant feldspar grains less than $1 \mathrm{~mm}$ long, whereas others have grains as large as $7 \mathrm{~mm}$. Garnet content ranges up to $10 \%$ with fine and coarse grains, and there is a few percent of amphibole in some of the pods. Biotite is a common constituent, occurring both as small parallel flakes and less as randomly oriented grains. Minor amounts of muscovite, zircon, tourmaline and sulfide minerals are also present, and sillimanite occur at the margins of a few pods. 

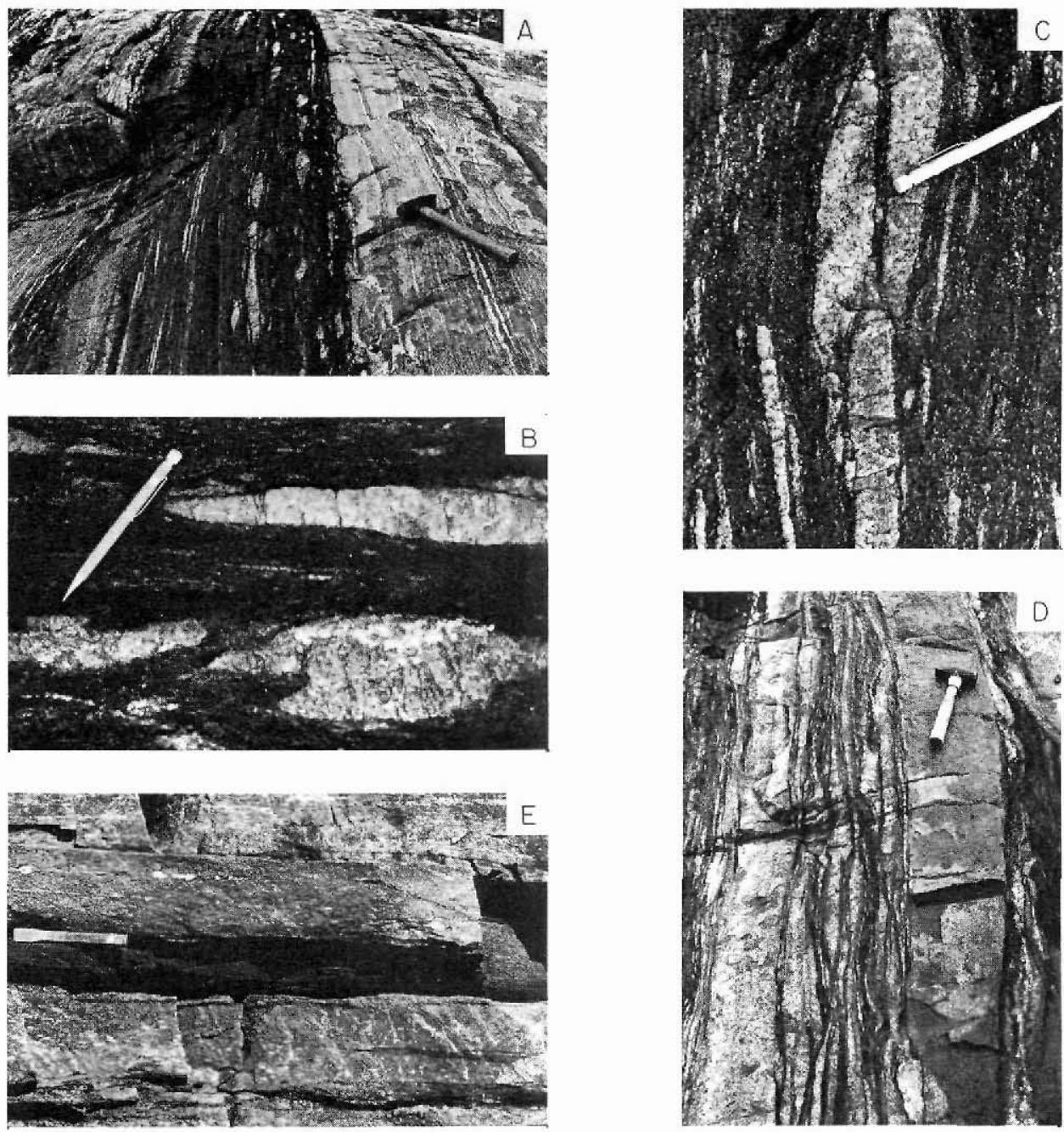

Fig. 5. Selected field photographs of the Malene metasedimentary rocks on Rypeø.

a. View of the first horizon of the 'pod-rock' at locality 1 (fig. 2). This unit (6 in fig. 4) contains quartzitic pods in a garnet- and biotite-rich matrix, and lies between two horizons of unit 5, a quartz-rich, rusty-weathering gray paragneiss.

b. Examples of 'pods' in unit 6 at locality 1 (fig. 2). The pod in the lower right hand corner is a transluscent white quartzite flattened against a pod containing quartz and coarse white feldspar. The longer, dark pod above these contains quartz and minor, fine-grained feldspar.

c. Three flattened garnet-bearing pods in unit 6 at locality 1 (fig. 2).

d. Upper horizons of the contact zone at locality 1 where unit 6 consists almost exclusively of large lenticular pods, and is interlayered with unit 7 , a massive, quartz-rich psammitic paragneiss.

e. A portion of the layered sequence at locality 4 (fig. 3). The white spots in the lower layer (unit b of fig. 6) are sillimanite-muscovite clots. A schematic stratigraphic column for this locality is detailed in fig. 6 . 
It is important to emphasize that all of the heterogeneities mentioned above occur among closely-spaced pods. Neither similar compositions nor similar textures are restricted to single horizons. In several cases, flattened adjacent pods are distinguishable by compositional differences rather than by the presence of intervening matrix. Metamorphic zonation locally alters pod composition to some degree: garnet and feldspar content changes from rim to core, for example. These differences do not form any pattern which immediately suggests paths of fluid migration however, nor is there a clear correlation of pod size and composition.

The pod-rock (Unit 6) alternates with a very pale brown quartz-rich psammitic gneiss (Unit 7). The latter contains $\sim 80 \%$ quartz, $\sim 10 \%$ plagioclase, $\sim 5 \%$ biotite, with traces of green muscovite, garnet, sulfide, ilmenite and rutile. Although Unit 7 appears homogeneous in outcrop, a sawn hand sample reveals layering of different grain sizes.

Unit 8 includes highly weathered, sulfide-rich layers with $\sim 20 \%$ quartz, $35 \%$ plagioclase, $25 \%$ biotite, $15 \%$ muscovite, and minor zircon and Fe-Ti oxide, and very coarse-grained layers (or lenses?) comprised of $\sim 90 \%$ quartz, $5 \%$ sillimanite, minor biotite, pyrite and zircon, and abundant $(\sim 5 \%)$ secondary muscovite. The rusty weathering here obscures the transition from Unit 7, and the gross layering features in Unit 8 itself.

Unit 9 is a massive to layered, quartz-rich paragneiss of undetermined thickness.

\section{Amîtsoq gneiss - Malene metasediment contact zone: southern supracrustal group}

A beach covers the Amitsoq-Malene boundary here (locality 3, fig. 3), but there are good exposures of a major mylonitized dike inland and on the east shore, indicating a fault boundary between the southern group of metasediments and Amitsoq gneiss. The metasediments in this region are dominantly massive quartz-rich types not unlike Unit 9 mentioned above.

Metasediments outside the contact zone. Most of the metasedimentary rocks outside the $20 \mathrm{~m}$ at the Amitsoq contact are some type of pale plagioclase-biotite-quartz gneiss. Quartz content ranges from $\sim 40-80 \%$ in the sampled massive units, with up to $\sim 45 \%$ plagioclase, $\sim 40 \%$ biotite, $\sim 20 \%$ muscovite, $\sim 15 \%$ microcline, $\sim 5 \%$ sillimanite, and $\sim 5 \%$ garnet, with zircon, tourmaline, sulfide and rutile the most common accessory phases.

Two generations of muscovite are present. It forms pale green to colorless retrograde rims on sillimanite, large but patchy, colorless alteration of plagioclase, and sharp, clean pale green to colorless grains, locally intergrown with biotite. The sillimanite-muscovite clots call attention to the relatively pelitic composition of the Rypeø rocks in the field, since they form pervasive, glistening splays on foliation planes. In cross-section the large clots at some outcrops form distinct quartz-rimmed lenses up to $3 \times 4 \mathrm{~cm}$. The details and significance of this clotted texture are described in the next section.

The fabric of these paragneisses ranges from an excellent planar parting in a blocky homogeneous rock to undulose, diffuse layering of quartzofeldspathic or silimanite-rich lenses. Grain size varies among samples as well, not only with respect to the development of sillimanite clusters but in the overall size distribution. All these textural differences are notable even within the southern group of metasediments where the folding is very gentle. Primary features such as fining or coarsening sequences, cross-laminations and ripple marks are perhaps the most plausible origin of the heterogeneities. Similar textural differences 
Fig. 6. Diagrammatic stratigraphic column for the metasedimentary lithologies at locality 4 (fig. 3).

a. Massive, fine-grained psammitic gneiss with indistinct fabric formed by biotite- and quartz-rich layers.

b. Layered unit containing quartz + plagioclase and quartitic bands with sillimanite-muscovite clots; the latter may have gray quartz rims and tirumaline-rich cores. Lower contact is gradational; the upper portion of the unit contains coarse-grained biotite-rich lenses $1-4 \mathrm{~cm}$ thick and $10-100 \mathrm{~cm}$ long.

c. Coarse-grained biotite- and plagioclase-rich layer identical in texture and mineralogy to lenses in b; lower contact is sharp.

d. Quartz-rich, biotite- and plagioclase-poor unit characterized by thin sillimanite-bright green mica layers and coarse rutile; lower contact is sharp.

e. Extremely coarse-grained lenses containing guartz, microcline, plagioclase, randomly-oriented sillimanite clusters and traces of biotite. The 'thick' portions of this unit are well-layered with biotite-rich laminae; lower contact is irregular.

f. Biotite- and sillimanite-rich layer with fine parting; lower contact is irregular. This unit is similar to the biotite-sillimanite horizon located on the map in figure 2.

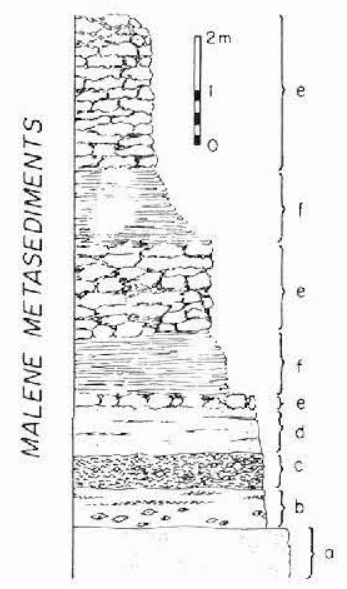

appear in the northern group of metasediments but it is more difficult to distinguish them in the midst of folding and local pegmatitic segregations.

Small cliffs of distinctive lithologies (cf. fig. 5e) occur within both the northern and southern massive metasedimentary sections. Figure 6 is a diagrammatic illustration of one well-exposed wall near the southern end of the metasediments (locality 4 in fig. 3). Virtually all of the lithologies of figure 6 appear in other parts of the island. In particular, a finelylaminated biotite-sillimanite layer (e.g. Unit f, fig. 6) acts as a marker horizon for the major structures of the northern group of metasediments (fig. 2).

\section{Other supracrustal rocks}

A series of predominantly metavolcanic rocks begins at the south end of the southern group of metasediments (fig. 3). After an initial strip of dark amphibolite containing garnet with plagioclase coronas, there is a section of very pale biotite amphibolites characterized by fine migmatitic layering and calc-silicate pods. Such calc-silicate horizons suggest that some of the amphibolites may have evolved from a carbonate-rich protolith rather than mafic to intermediate volcanic rocks. The transition from the pale grey metavolcanic rocks to dark amphibolite on figure 3 denotes only a change in dominant lithologies. Similar concordant pale grey units do occur farther south amidst a series of more typical dark amphibolites.

Deformation at the contact between the metasedimentary and metavolcanic rocks combined with incomplete exposure make their relationship ambiguous. In addition, reaction of the metasediments (sillimanite-garnet-biotite rock) with an intervening pinched-out ultramafic layer has created a $10-20 \mathrm{~cm}$ skarn zone containing lavender corundum porphyroblasts (up to $15 \mathrm{~cm}$ long), pleonaste spinel and gedrite, which also obscures contact relationships. 


\section{Discussion and interpretation}

The Malene Supracrustals on Rypeø have been strongly deformed and it is virtually impossible to evaluate the effects of tectonic thickening and thinning. Nevertheless, the overall aspect of the metasediments is consistent with formation in a near-shore depositional environment. The interlayering of units which are (1) coarse- and fine-grained, (2) quartzrich and mica-rich, (3) massive to well-laminated, and (4) lensoidal and pod-bearing, all suggest original alternation of sandy, silty, and muddy sediments. The quartz- and feldsparrich nature of most of the rocks indicates a protolith dominated by impure arkosic sediments that could have developed in either a beach, tidal or fluviatile situation.

Observations on the 'pod-rock' lead to several hypotheses for its origin. The variety of pod compositions, the absence of connecting quartz stringers or mafic selvages, and the separation of the pod-rock from the most tectonized part of the Malene-Amitsoq contact zone appear to rule out a tectonic breccia. The fact that the larger pods are never surrounded by smaller, more-deformed pods reinforces this rejection. The relatively quartz-rich composition of the contact zone rocks, and the bedded structure of the pod-rock unit itself and associated metasediments, all contraindicate a volcanic breccia.

A classic basal conglomerate hypothesis appears inadequate as well. The pods in this unit resemble lithologies in the metasedimentary sequence rather than granitoid gneisses, and the pod-rock is not in contact with Amîtsoq gneiss. In addition, the relatively garnet- and biotite-rich matrix composition contrasts with an expected arkosic host. Moreover, this unit is matrix-supported rather than clast-supported.

An origin for the pod-rock as some type of intraformational conglomerate, or as interlayered sandy to silty layers/lenses appear equally plausible. Quartzitic clasts in a sandy matrix along with silt- or mudstone rip-up clasts are common features of tidal and fluviatile sedimentary environments. An abundance of rip-up clasts derived from adjacent Malene sediments could well account for the 'matrix'-supported structure of the existing rocks. Interbedded sand-, silt- and mudstone-competent and incompetent layers or lenses - could also constitute the parent of the pod-rock, although the commonly rounded ends and variable pod compositions are more difficult to reconcile with this idea. Original heterogeneity in the sedimentary protolith combined with the effects of deformation and metamorphism could conceivably produce the observed lithological variation. The pods illustrated in figure $5 \mathrm{c}$ do seem more like lenses than flattened cobbles.

Whatever the subtleties of these arguments, the principal point here is that both rip-up structures and the interlayering of sandy, silty, and muddy horizons are likely to occur at different stages in the same depositional environment. The observed features of the podrock and the whole group of metasediments are reasonable for a 'continental'-margin sedimentary environment independent of whether the pods are lenses or clasts.

One can speculate about additional observations on small-scale features. Do some zones of truncated layering prepresent preserved cross-bedding or channel cuts, or are they transposition fabrics? Are some of the textural variations related to pebbly layers, sand-filled mud cracks or water release structures? Such possibilities are probably infinitely arguable; the overall heterogeneity in the gross lithological layering and composition of the original sedimentary material is not.

Our inferences regarding a near-shore depositional environment for the protolith of the Malene metasediments on Rypeø, combined with their quartz-rich compositions and close 
spatial association with Amîtsoq gneiss, favor a basement-cover relationship. General concordance of layering in the Malene supracrustal rocks and in the Amitsoq gneiss, and the abrupt change from microcline-rich (Amîtsoq) to plagioclase-rich (Malene) rocks, certainly does not require that the sediments be derived from the immediately adjacent gneiss, but neither do any of our observations require that kilometers of thrust movement occurred along the present contact. Moreover, the occurrence of individual units in similar stratigraphic positions along several hundred meters of strike length (see fig. 2 and earlier), argue in favor of a little-disrupted primary contact zone.

\section{Mineralogy and metamorphism}

\section{Petrography and mineral-chemistry}

Two samples of massive brown garnet-biotite-sillimanite paragneiss from the southern group of metasediments have been studied in detail. Below we present brief petrographic descriptions and mineral-chemical data for each, followed by a discussion of the petrological implications of these results.

Table 1. Microprobe analyses of garnet, Rypeø

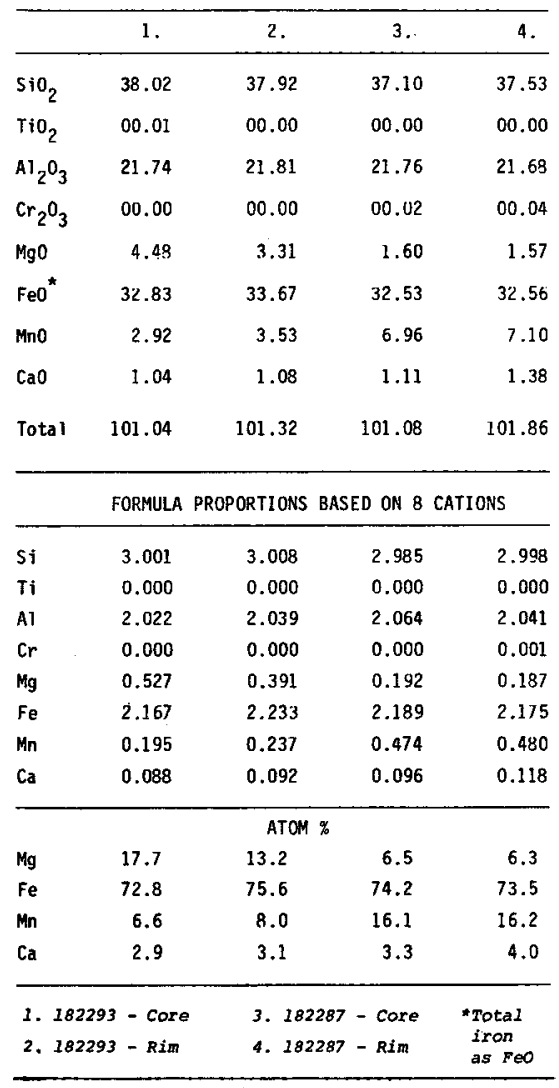


Table 2. Microprobe analyses of muscovite and biotite, Rypeø

\begin{tabular}{|c|c|c|c|c|c|}
\hline & 1. & 2. & 3. & 4. & 5. \\
\hline $\mathrm{SiO}_{2}$ & 36.59 & 46.16 & 36.33 & 45.52 & 45.41 \\
\hline $\mathrm{TiO}_{2}$ & 1.83 & 0.33 & 2.67 & 0.79 & 0.00 \\
\hline $\mathrm{Al}_{2} \mathrm{O}_{3}$ & 20.15 & 36.75 & 17.68 & 35.90 & 37.43 \\
\hline $\mathrm{MgO}$ & 11.66 & 0.70 & 7.86 & 0.68 & 0.15 \\
\hline $\mathrm{Fe} 0^{\star}$ & 16.17 & 1.30 & 22.03 & 1.51 & 1.06 \\
\hline Mno & 0.08 & 0.02 & 0.23 & 0.02 & 0.00 \\
\hline $\operatorname{Zn} 0$ & 0.10 & 0.00 & 0.08 & 0.00 & 0.00 \\
\hline $\mathrm{CaO}$ & 0.00 & 0.00 & 0.00 & 0.00 & 0.00 \\
\hline $\mathrm{Na}_{2} \mathrm{O}$ & 0.15 & 0.48 & 0.07 & 0.34 & 0.34 \\
\hline $\mathrm{K}_{2} \mathrm{O}$ & 9.71 & 9.88 & 9.78 & 11.32 & 10.75 \\
\hline \multirow[t]{2}{*}{ Total } & 96.48 & 95.63 & 96.83 & 95.98 & 95.16 \\
\hline & \multicolumn{5}{|c|}{ FORMULA PROPORTIONS BASED ON 11 OXYGENS } \\
\hline \multirow{2}{*}{$(I V)$} & 2.702 & 3.045 & 2.763 & 3.026 & 3.021 \\
\hline & 1.298 & 0.955 & 1.237 & 0.974 & 0.979 \\
\hline A1 & 0.457 & 1.904 & 0.348 & 1.840 & 1.958 \\
\hline Ti & 0.102 & 0.016 & 0.153 & 0.039 & 0.000 \\
\hline \multirow{2}{*}{$\operatorname{lo}_{e}(V I)$} & 1.284 & 0.069 & 0.891 & 0.067 & 0.015 \\
\hline & 0.999 & 0.072 & 1.401 & 0.083 & 0.059 \\
\hline $\mathrm{An}$ & 0.005 & 0.001 & 0.015 & 0.000 & 0.000 \\
\hline Zn & 0.006 & 0.000 & 0.005 & 0.000 & 0.000 \\
\hline $\mathbf{C a}$ & 0.000 & 0.000 & 0.000 & 0.000 & 0.000 \\
\hline $\mathrm{Na}$ (A) & 0.022 & 0.061 & 0.011 & 0.044 & 0.044 \\
\hline K & 0.915 & 0.831 & 0.949 & 0.951 & 0.912 \\
\hline \multicolumn{3}{|c|}{$\begin{array}{l}\text { 1. Biotite - } 182293 \\
\text { 2. Muscovite (Secondary) - } 182293 \\
\text { *Total iron as FeO }\end{array}$} & \multicolumn{3}{|c|}{$\begin{array}{l}\text { 3. Biotite - } 182287 \\
\text { 4. Muscovite (Primary) }-182287 \\
\text { 5. Muscovite (Secondary) - } \\
182287\end{array}$} \\
\hline
\end{tabular}

182293. This sample is a well-foliated gneiss containing millimeter to centimeter-size sub-rounded grains of quartz $(\sim 40 \%)$ and plagioclase $\left(\sim 40 \% ; \mathrm{An}_{22-24}\right)$, with $\sim 10 \%$ biotite, and $\sim 5 \%$ each of garnet and sillimanite. Trace amounts of accessory apatite, graphite, rutile, sulfide minerals, tourmaline and zircon are also present.

Garnet forms rounded pinkish-brown porphyroblasts up to $\sim 3 \mathrm{~mm}$ across with tiny subequant inclusions of quartz, plagioclase and oxide. It is Fe-rich, with average composition $\sim \mathrm{Alm}_{75} \mathrm{Pyr}_{15} \mathrm{Sp}_{7} \mathrm{Gr}_{3}$. Slight retrograde compositional zoning is present in garnet, with rims being more Fe-rich than cores (Table 1, No. 1 and 2). Biotite is strongly pleochroic from yellow-brown to red-brown, and forms stubby plates up to $\sim 1 \mathrm{~mm}$ long. Individual grains are homogeneous $[\mathrm{Fe} /(\mathrm{Fe}+\mathrm{Mg})=0.42-0.46]$, but $\mathrm{TiO}_{2}$-content $(\sim 1.4-1.9 \mathrm{wt} \%)$ varies somewhat from area to area in the thin section analyzed (Table 2, No. 1). Sillimanite occurs as sub-millimeter sized prismatic grains that locally form lense-shaped aggregates up to $\sim 1 \mathrm{~mm}$ long. A trace of fine-grained white mica locally replaces biotite and garnet (Table 2, No. 2).

182287. This sample is also a well-foliated quartz-rich gneiss with abundant plagioclase $(\sim 40 \%$, $\left.\mathrm{An}_{20-22}\right)$, perthitic alkali feldspar $\left(\sim 5 \% ; \sim \mathrm{Or}_{90}\right)$, biotite $(\sim 15 \%)$, garnet $(\sim 5 \%)$, muscovite $(\sim 20 \%)$ and a trace of sillimanite. The high abundance of muscovite relative to sillimanite and alkali feldspar is due to the occurrence of two types: a coarsely crystalline primary variety and a finer grained secondary type that forms 'clots' replacing sillimanite (see earlier). Accessory apatite, graphite, rutile, sulfide minerals, tourmaline and zircon also are present.

Garnet occurs as rounded millimeter-sized pinkish-brown porphyroblasts that are commonly repla- 
ced by fine-grained white mica and minor chlorite. The garnet is $\mathrm{Fe}$ - and $\mathrm{Mn}-\mathrm{rich}$, with average composition $\sim \mathrm{Alm}_{74} \mathrm{Pyr}_{7} \mathrm{Sp}_{16} \mathrm{Gr}_{3}$ (Table 1, No. 3 and 4). Analyzed grains display virtually no zoning, and may have equilibrated during retrogression. Biotite is strongly pleochroic from pale to dark brown, and forms stubby plates up to $\sim 2 \mathrm{~mm}$ long. It is $\mathrm{TiO}_{2}$-rich $(2.8 \mathrm{wt} \%)$, and shows little variation in composition $[\mathrm{Fe} /(\mathrm{Fe}+\mathrm{Mg}) \sim 0.61]$ (Table 2, No. 3). Sillimanite occurs in sub-millimeter sized aggregates comprised of 10-50 $\mu \mathrm{m}$ acicular grains. Primary muscovite (Table 2, No. 4) forms tabular grains up to $\sim 1 \mathrm{~mm}$ long that are commonly kinked. It contains modest amounts of $\mathrm{TiO}_{2}(0.6-0.8 \mathrm{wt} \%)$, $\mathrm{MgO}(0.5-0.7 \mathrm{wt} \%), \mathrm{FeO}_{\mathrm{T}}(1.5-2.2 \mathrm{wt} \%)$ and $\mathrm{Na}_{2} \mathrm{O}(\sim 0.5 \mathrm{wt} \%)$. Secondary muscovite (Table 2 , No. 5) is typically intergrown with quartz; it contains no detectable $\mathrm{TiO}_{2}$, and, compared to primary muscovite, has smaller amounts of $\mathrm{MgO}(\sim 0.1 \mathrm{wt} \%)$ and $\mathrm{FeO}_{\mathrm{T}}(\sim 1.0 \mathrm{wt} \%)$, but similar $\mathrm{Na}_{2} \mathrm{O}$.

\section{Phase petrology considerations}

The above minera-chemical data are summarized on an AFM diagram in figure 7, which emphasizes the compositional differences between the two samples: garnet and biotite in 182287 are substantially more Fe-rich than those in 182293. The crossing tie-lines are an artifact of projection, and not a result of disequilibrium conditions.

First of all, 182293 contains the three phase assemblage Bio-Garn-Sill, whereas 182287 also contains muscovite (the occurrence of Kfsp in 182287 is discussed below). Thus, topologically, 182287 represents a four-phase tietetrahedron that is bounded on its $\mathrm{Mg}$-rich side by a series of three-phase tie-triangles (such as 182293), all of which 'point' into the plane of figure 7 . Hence, crossing tie-lines result only when biotite compositions are projected onto the AFM plane.

The textures in 182287 indicate that it preserves evidence for the prograde breakdown of muscovite, expressed by the simplified reaction: muscovite + quartz $=$ sillimanite $+\mathrm{K}-$ feldspar, as well as evidence for the reverse reaction in which muscovite replaces sillimanite. Our analyses of the primary muscovite in this sample (Table 2, No. 4) show that it does not have the pure end-member composition [i.e. $\mathrm{KAl}_{2} \mathrm{Si}_{3} \mathrm{Al}_{10}\left(\mathrm{OH}_{2}\right)$ ]. Therefore, the actual breakdown reaction is more complex than the one listed above, involving at least one additional phase (plagioclase), as well as biotite and garnet. Hence, there is a 'transition zone' where muscovite, sillimanite, alkali feldspar and plagioclase (and garnet + biotite + quartz) all coexist in prograde reaction relation. Tracy (1978) has studied such a transition zone in central Massachusetts, USA, and noted (personal communication) textural evidence for prograde and retrograde reactions identical to those observed by us in the samples on

Fig. 7. AFM diagram for the two Malene me-

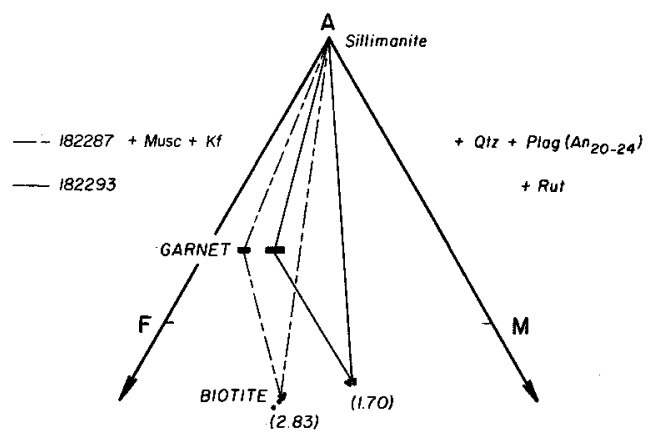
tasedimentary rocks discussed in the text. Numbers in parentheses next to the biotite composition points are the average $\mathrm{Wt} \% \mathrm{TiO}_{2}$ in each. Crossing biotite-sillimanite tie-lines are an artifact of projection, as discussed in the text. 
Rypeø. The major point here is that these textural and mineralogical features all indicate a complex high-grade polymetamorphic history for the Malene metasediments on Rypeø.

\section{Estimated conditions of metamorphism}

Using $\mathrm{Mg}-\mathrm{Fe}$ partitioning between garnet and biotite in sample 182293, we obtain $\mathrm{T} \sim$ $575^{\circ} \mathrm{C}$ based on the experimentaly calibrated results of Ferry \& Spear (1978). Since the garnet shows retrograde zoning, and we may not have analyzed the most $\mathrm{Mg}$-rich cores that formed at the peak of metamorphism, we feel that this value represents a minimum temperature estimate. Because of its high Mn-content, the garnet in 182287 falls outside the range in which the geothermometer can be applied.

Regional metamorphism of the Malene supracrustals in the Godthåb district and surrounding region of West Greenland occurred at a pressure greater than that of the aluminosilicate triple point isobar (e.g. Dymek, 1978; Wells, 1976), and we will assume that $P \sim 5 \mathrm{~kb}$ is a reasonable estimate for the sillimanitic gneisses on Rypeø. Since the metasediments on Rypeø show some evidence for localized partial melting, and since there is good evidence for prograde muscovite breakdown, we feel that a temperature for metamorphism as high as $\sim 650^{\circ} \mathrm{C}$ is possible. We interpret the apparent disagreement between this value and that calculated from $\mathrm{Mg}-\mathrm{Fe}$ partitioning as a result of retrograde equilibration.

\section{Rare earth element geochemistry}

\section{Introduction and results}

Four samples were analyzed for eight rare earth elements (REE) using isotope dilution mass spectrometric techniques, and the results are illustrated in figure 8 . There is a strong similarity among the four data sets, despite the fact that distinct lithologies were analyzed. The overall low REE abundances are unusual, but consistent with the high quartz contents of the samples. The strongly-fractionated patterns, particularly for the heavy REE, are also atypical for sedimentary rocks: we feel that this feature was inherited from the source region(s) of the sediments. The slight to moderate positive europium anomaly can be ascribed with caution to a plagioclase component in the sedimentary protolith, whereas the slight upturn for the heavy REE in 1590 and 2130 is probably related to the higher modal abundance of zircon in these samples. Since zircon strongly concentrates the heavy REE, this interpretation seems rather straightforward.

\section{Discussion}

The REE are generally considered to be immobile and not fractionated in most surface environments and processes. Therefore, REE in sediments can be powerful tracers for the rock types that contribute detritus to them, although REE in any sediment will represent the 'average' of the source region. Consequently, unless extensive melting has taken place, the overall shape of a REE pattern in metasedimentary rocks will record features established in the sedimentary protolith.

Some small-scale localized partial melting appears to have occurred on Rypeø, which could introduce uncertainty into the interpretation of our data. However, we have selected 
Fig. 8. Rare earth element abundances in four Malene metasedimentary rocks from Rypeø; see text for discussion.

2130: Coarse, biotite-rich paragneiss (unit $\mathrm{c}$ of fig. 6) containing $\sim 40 \%$ each of biotite and plagioclase, $\sim$ $20 \%$ quartz, minor sulfide minerals and abundant accessory zircon.

1590: Fine-grained psammitic gneiss from southern group of metasediments containing $\sim 75 \%$ quartz, $\sim$ $15 \%$ plagioclase, $\sim 5 \%$ biotite, $\sim 5 \%$ muscovite, and minor sillimanite and microcline, with abundant accessory tourmaline and zircon.

2138: Coarse-grained psammitic gneiss from the southern group of metasediments containing $\sim 75 \%$ quartz, $\sim 10 \%$ each of plagioclase and biotite, $\sim 1 \%$ muscovite and microcline, and traces of zircon, tourmaline, and sulfide minerals.

2111: Layered quartz-rich paragneiss (unit 5 of contact zone, locality 1 on fig. 2).

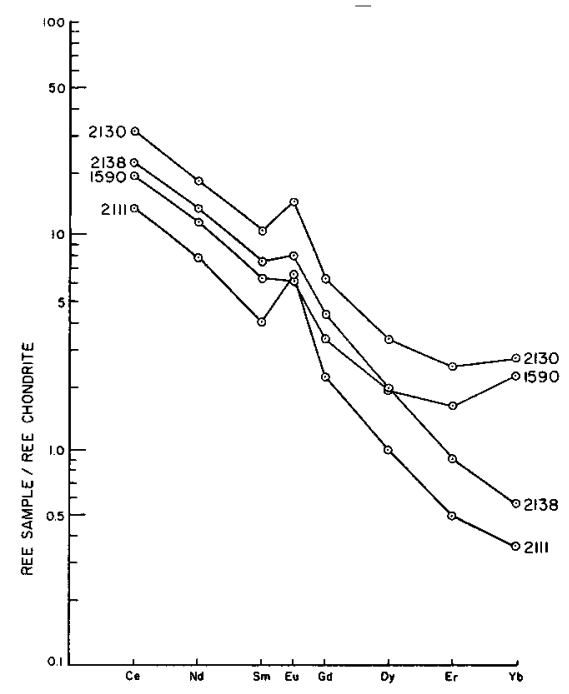

samples for analysis from homogeneous layers free of any veining. Moreover, we feel confident that the overall internal consistency of our data argues against any problems related to melting.

The REE patterns and abundances in the Rypeø samples are unlike those reported in Archaean 'shales' by S. R. Raylor and co-workers (summarized in Taylor, 1979). Archaean 'shales' have higher overall REE abundances, and flat, unfractionated heavy REE. However, our data are remarkably similar to the few analyses reported for 'tonalitic' Amîtsoq gneiss (cf. O'Nions \& Pankhurst, 1978). Moreover, certain features of the Amîtsoq gneiss REE data (low abundances, strongly-fractionated patterns, small positive Eu anomalies) are shared by many Archaean tonalitic, trondhjemitic and granodioritic rocks (cf. Arth \& Hanson, 1975).

A general discussion of the causes and consequences of REE patterns in Archaean metasedimentary rocks is clearly beyond the scope of this report, but it is difficult to imagine either a source material or process that could produce the observed REE patterns beyond simple weathering and erosion of Amitsoq gneiss. Therefore, the most simple interpretation of the Malene metasedimentary rocks on Rypeø is that they are dominated by material derived locally from Amitsoq gneiss, which is consistent with the geological observations presented previously.

\section{Conclusions and implications}

The data and observations presented in this paper lend credence to the hypothesis that Malene metasediments were deposited unconformably on a basement of older Amitsoq gneiss. Thus we are in basic agreement with the suggestion of Chadwick \& Nutman (1979) regarding the original nature of the Amitsoq-Malene boundary, but we feel that metasediments such as are found on Rypeø constitute the basal units rather than amphibolite. Of course, if there was an Amitsoq 'continent' bounded by mafic 'oceanic' crust, then it is quite 
probable that Malene sediments were deposited on both, with all rock types interleaved tectonically at a later time to account for the presently observed field relationships. This raises intriguing possibilities as to the age of the Malene amphibolites, and their relationship to Malene metasediments. Other Malene units, such as the widespread 'cordierite-anthophyllite rocks' (CAR) require additional study before their position in any regional stratigraphic models can be ascertained.

Observations on the metamorphism of the Malene supracrustals presented here and elsewhere (cf. Dymek, 1978), combined with recently published results for the older $~ 3800$ Ma Isua Supracrustal rocks (Boak \& Dymek, 1980; Boak et al., 1983) and their lithologically correlative enclaves in Amîtsoq gneiss - the Akilia association (Griffin et al., 1980) have important implications for the tectonic evolution of the Archaean crust of southern West Greenland. Specifically, the Amîtsoq gneiss underwent high grade metamorphism at $c$. $3600 \mathrm{Ma}$ with inferred depths of burial $\sim 15-25 \mathrm{~km}$, followed by uplift, erosion and deposition of Malene sediments before about $3000 \mathrm{Ma}$. Later metamorphism of the Amitsoq-Malene pile occurred at $\sim 2800 \mathrm{Ma}$ also under high-grade conditions with inferred depths of burial of $\sim 15-25 \mathrm{~km}$. Even though tectonic thickening by lateral crustal movements was probably very important (cf. Bridgwater et al., 1974), the total inferred amount of vertical movement was substantial, perhaps as great as $75 \mathrm{~km}$ based on the above scenario. It is unclear what specific implications this observation has for isostatic compensation and the rheology of the Archaean mantle, but it places certain boundary conditions on geophysical modelling of the early Earth.

Acknowledgments. This work has been carried out with the financial support of the National Science Foundation (Grants DES 75-03417 and EAR 78-23412), and the Daly and Shaler Funds of Harvard University. Additional support for field work in 1979 was provided by a grant from the National Geographic Society. RFD was supported in the field in 1975 by the Geological Survey of Greenland. We thank A. A. Chodos (Caltech) for carrying out the microprobe analyses, and G. M. Smith and J. L. Boak (Harvard) for discussions. Comments on the manuscript by staff members of the Geological Survey of Greenland have been most useful. Details of the analytical procedures used are available from the authors upon request.

\section{References}

Arth, J. G. \& Hanson, G. N. 1975: Geochemistry and origin of the early Precambrian crust of northeastern Minnesota. Geochim. cosmochim. Acta 39, 325-362.

Beech, E. M. \& Chadwick, B. 1980: The Malene supracrustal gneisses of northwest Buksefjorden: their origin and significance in the Archaean crustal evolution of southern West Greenland. Precambian Res. 11, 329-356.

Boak, J. \& Dymek, R. F. 1980: An occurrence of kyanite at Isua, West Greenland and implications for early Archaean geothermal gradients. Geol. Soc. Amer. Abstr. 12, 389 only.

Boak, J. L., Dymek, R. F. \& Gromet, L. P. 1983: Petrology and rare earth element geochemistry of clastic metasedimentary rocks from the Isua supracrustal belt, West Greenland. Rapp. Grønlands geol. Unders. 112, 23-33.

Bridgwater, D., McGregor, V. R. \& Myers J. S. 1974: A horizontal tectonic regime in the Archaean of Greenland and its implications for early crystal thickening. Precambrian Res. 1, 179-197.

Bridgwater, D., Keto, L., McGregor, V. R. \& Myers, J. S. 1976: Archaean gneiss complex of Greenland. In Escher, A., \& Watt, W. S. (edit.) Geology of Greenland, 20-75. Copenhagen: Geol. Surv. Greenland. 
Chadwick, B. \& Nutman, A. 1979: Archaean structural evolution in the northwest part of the Buksefjorden region, southern West Greenland. Precambrian Res. 9, 199-226.

Dymek, R. F. 1977: Mineralogic and petrographic studies of Archaean metamorphic rocks from West Greenland, lunar samples, and the meteorite Kapoeta. 342 pp. Unpublished Ph.D. dissertation, California Institute of Technology, Pasadena.

Dymek, R. F. 1978: Metamorphism of Archaean Malene Supracrustals, Godthåb District, West Greenland. (Abstract). In Smith, I. E. M. \& Williams, J. D. (edit.). Proceedings. 1978 Archean Geochemistry Field Conference, 339-342. University Toronto Press.

Ferry, J. M. \& Spear, F. S. 1978: Experimental calibration of the partitioning of Fe and Mg between biotite and garnet. Contr. Miner. Petrol. 66, 113-117.

Griffin, W. L., McGregor, V. R., Nutman, A., Taylor, P. N. \& Bridgwater, D. 1980: Early Archaean granulite-facies metamorphism south of Ameralik, West Greenland. Earth planet. Sci. Lett. 50, 59-74.

McGregor, V. R. 1973: The early Precambrian gneisses of the Godthåb District, West Greenland. Phil. Trans. R. Soc. London A273, 343-358.

McGregor, V. R. \& Mason, B. 1977: Petrogenesis and geochemistry of metabasaltic and metasedimentary enclaves in the Amîtsoq Gneisses, West Greenland. Amer. Mineral 62, 887-904.

Nutman, A. P. \& Bridgwater, D. 1983: Deposition of Malene supracrustal rocks on an Amîtsoq basement in outer Ameralik, southern West Greenland. Rapp. Grønlands geol. Unders. 112, 43-51.

O'Nions, R. K. \& Pankhurst, R. J. 1978: Early Archaean rocks and geochemical evolution of the crust. Earth planet. Sci. Lett. 38, 211-236.

Smith, G. M. \& Dymek R. F. 1983: A description and interpretation of the Proterozoic Kobbefjord Fault Zone, Godthåb district, West Greenland. Rapp. Grønlands geol. Unders. 112, 113-127.

Taylor, S. R. 1979: Chemical composition and evolution of the continental crust: the rare earth element evidence. In McIlhenney (edit.) The Earth: Its Origin, Structure, and Evolution, 353-376. Academic Press.

Tracy, R. J. 1978: High-grade metamorphic reactions and partial melting in pelitic schist, west-central Massachusetts. Amer. J. Sci. 278, 150-178.

Wells, P. R. A. 1976: Late Archaean metamorphism in the Buksefjorden region, southwest Greenland. Contr. Miner. Petrol. 56, 229-242.

R.F.D. \& R.W., Department of Geological Sciences, Harvard University, Cambridge, Massachusetts 02138, USA.
L.P.G., Department of Geological Sciences, Brown University, Providence, RI 02912, 